\title{
Zerumbone's Effects on Jurkat Cell Proliferation and Migration
}

\author{
Cheol Moon \\ Department of Clinical Laboratory Science, Semyung University, Jecheon 27136, Korea
}

\section{Zerumbone이 Jurkat 세포의 증식과 유주에 미치는 영향}

\author{
문 철
}

세명대학교 임상병리학과

\begin{abstract}
Zerumbone is a major component of the essential oils of Zingiber zerumbet Smith and is known to have a number of effects on the functions of various cells, including immune cells. Many reports present the zerumbone's functions in various biological environments including cancer and inflammation. In this report, using a transwell system, we confirmed that zerumbone decreased the stromal cell-driven factor- $1 \alpha$ (SDF-1 $\alpha$ ), induced migration of Jurkat cells; about a $25 \%$ decrease in the case of $100 \mathrm{ng} / \mathrm{mL} \mathrm{SDF-1} \alpha$ treatment, $17 \%$ decrease in the case of $200 \mathrm{ng} / \mathrm{mL}$. Whereas, no significant changes of basic cellular proliferation were observed after zerumbone treatment. These results are novel and promising functions of zerumbone on T cell physiology. At the same time, there is a great need to confirm the results using more physiological T cells and to proceed with cellular and biochemical mechanism studies, measuring apoptosis, CXCR4 expression and phosphorylation of ZAP-70 and Erk1/2.
\end{abstract}

Keywords: Migration, Proliferation, T lymphocyte, Zerumbone

This is an Open Access article distributed under the terms of the Creative Commons Attribution Non-Commercial License (http://creativecommons.org/licenses/by-nc/4.0) which permits unrestricted non-commercial use, distribution, and reproduction in any medium, provided the original work is properly cited.

Copyright (c) 2015 The Korean Society for Clinical Laboratory Science. All rights reserved.
Corresponding author: Cheol Moon Department of Clinical Laboratory Science, Semyung University, Jecheon 27136, Korea Tel: 82-43-649-1419

E-mail: antigene@semyung.ac.kr

Received: October 30, 2015

Revised $1^{\text {st: }}$ November 10, 2015

Revised 2 ${ }^{\text {nd }}$ : November 13, 2015

Revised $3^{\text {rd: }}$ November 13, 2015

Accepted: November 13, 2015

\section{서 론}

야생 생강의 일종인 Zingiber zerumbet Smith의 정유 (essential oil)에 포함되어 있는 주요성분인 zerumbone은 다양한 연구를 통해 혈액종양을 포함한 암, 염증질환, 활성산소 감소 등에 이용할 가능성이 꾸준히 제기되어왔다(Murakami와 Ohigashi, 2006; Sulaiman 등, 2010; Perimal 등, 2011). 또한 면역세포들의 증식과 세포주기진행, 싸이토카인의 생성 - 발현에도 효과를 나타 낸다고 알려져 있다(Keong 등, 2010). 이외에도 간보호, 통증완화, 항동맥경화, 항미생물 등 다양한 생물학적 기능이 보고되었다 (Kitayama 등, 2004; Eguchi 등, 2007; Sulaiman 등, 2009; Taha
등, 2010; Perimal 등, 2011). 다양한 zerumbone의 기능 가운데 항암효과에 대한 연구가 활발히 진행되고 있다. 신장상피세포암 세 포주와 이종이식 모델을 이용한 연구를 통해 zerumbone이 signal-transducer and activator of transcription (STAT)3의 활 성을 저하시켜 암세포의 증식, 생존, 혈관형성을 억제함이 보고 되 었으며(Shanmugam 등, 2015), 췌장 상피암의 경우에는 p53신호 전달 체계의 활성화를 통해 암세포의 자가사멸을 유도함이 알려졌 다(Zhang 등, 2012). 이외에도 간암, 위암, 피부암, 담도암 등 다양 한 암세포의 세포자멸사 유발, 전이 방지 효능을 지닌 것으로 알려 져 있다. 아울러, 항염증 효능도 다양한 연구에 의해 보고되었는데, dextran sodium sulfate (DSS)를 이용하여 mice에 유발시킨 급성 
궤양성장염 증세가 zerumbone 식이를 통해 호전되었으며 (Murakami 등, 2003), 콜라겐을 통해 관절염을 유발시킨 렛트에게 zerumbone 화합물을 먹인 경우 증세가 호전되었다는 보고도 있 다(Murakami 등, 2007). 또한 zerumbone의 면역조절 기능도 보 고되었다. 실험용 mouse의 흉선, 비장으로부터 얻은 세포와 사람 의 말초혈액으로부터 얻은 단핵세포(peripheral blood mononuclear cell, PBMC)의 증식이 zerumbone에 의해 증가되었으며, $\mathrm{G} 2 / \mathrm{M}$ 세포주기 집중현상, 그리고, interleukin (IL)-2, IL-12 생성/ 분비 증가도 관찰되었다(Keong 등, 2010).

면역세포의 체내 이동(migration)은 적절한 면역반응을 위해 매 우중요하다(Bordon, 2011). 면역세포 중 림프구들은 획득면역기 능에 핵심적인 역할을 수행하는 세포들로써, 지속적으로 혈액, 림 프액, 림프조직과 여타 조직 사이를 순환한다. 아직 항원 특이성을 나타내지 않는 신생 림프구들은 신체순환을 통해 외부의 환경과 거 의 직접적으로 접촉할 기회를 갖거나, 다양하게 제시되는 항원들을 접촉할 기회를 얻는다. 또한, 항원 특이성을 지닌 소수의 림프구들 은 신체를 순환하며 동일한 특이 항원을 다시 만날 기회를 갖게 된 다. 이와 같은 림프구들의 신체순환을 통한 항원 접촉 현상은 시기 와 장소에 따른 적절한 면역반응의 발현, 조절에 결정적인 영향을 미친다. 그러므로, 림프구들의 신체순환은 매우 다양한 분자들을 통해 엄격하게 조절된다. 림프구의 움직임을 조절하는 분자들에 대 한 많은 연구가 진행 중인데, 대표적인 분자들로 케모카인(chemokine)과 케모카인 수용체(chemokine-receptor), 접촉분자로 통칭되는 셀렉틴(selectin), 어드레신(addressin), 인테그린(integrin) 등이 있다(Bordon, 2011). 이렇듯 복잡하게 조절되는 면역세포 이 동현상의 정확한 조절 기작에 대한 많은 연구가 진행되고 있으며, 이를 통해 다양한 면역질환과 종양의 발병 및 진행에 대한 깊이 있 는 이해가 가능할 것으로 기대하고 있다. 더욱이, 면역세포 이동현 상 조절 기작에 대한 이해를 바탕으로 인위적 이동현상 조절을 통 한 질환 치료에 대한 실마리를 얻을 수 있을 것으로 생각된다.

본 연구에서는 염증반응, 암세포를 비롯한 면역세포에 다양한 기능을 나타내는 zerumbone이 T세포 이동에 대해서는 어떠한 영 향을 미치는가를 알아보았다. 이를 위해 케모카인의 일종인 SDF- $1 \alpha$ 를 이용하여 사람 $\mathrm{T}$ 세포주인 Jurkat 세포의 이동을 유도하였고, zerumbone이 SDF-1 $\alpha$ 유발 Jurkat 세포의 이동을 감소시키는 현 상을 관찰할 수 있었다. 반면에 water soluble tetrazolium (WST) 을 이용한 cell viability 측정을 통해 zerumbone이 Jurkat 세포의 증식에는 영향을 미치지 않음을 확인하였다. 본 연구를 통해, 간단 하지만 분명하게 확인된 zerumbon의 기능은 추후에 보다 생리적 인 세포(사람 말초혈액 T세포 혹은 실험용 쥐의 $\mathrm{T}$ 세포)를 대상으로 확인되어야 할 것이며, 세포학적 - 생화학적 기전에 대한 추가 연구
가 필요할 것으로 생각된다.

\section{재료 및 방법}

\section{1. 시약}

본 연구에서 사용된 시약은 Zerumbone (Sigma-Aldrich Co., St. Louis, MO, USA)와 Stromal cell-derived factor- $1 \alpha(\mathrm{SDF}-1 \alpha)$ (R\&D Systems Co., Minneapolis, USA)이었다.

\section{2. 세포배양}

Jurkat 세포주(clone E6-1; JE6-1, KCLB No. 40152)는 한국세 포주은행으로부터 분양 받았다. 세포배양액은 Roswell Park Memorial Institute (RPMI) 1640 medium with L-glutamine (Lonza, Walkersvill, MD, USA)에 10\%(v/v) Fetal bovine serum (FBS) (Gibco, Co., Grand Island, NY, USA), 1\% (v/v) Penicillin/Streptomycin (Gibco, Co., Grand Island, NY, USA), 1\%(v/v) 4-(2-hydroxyethyl)-1-piperazineethanesulfonic acid (HEPES) (Welgene Inc., Daegu, Korea), 1\% (v/v) non-essential amino acid (Welgene Inc., Daegu, Korea)를 첨가하여 사용하였 다. 배양은 $37^{\circ} \mathrm{C}, 5 \% \mathrm{CO}_{2}$ 조건을 맞춘 배양기를 이용하여 진행하 였다. 세포 이동 평가를 위한 transwell migration assay는 FBS free migration 배지를 사용하여 진행하였는데, RPMI 1640 배지 를 기본으로 하여 상기 첨가물 중에서 FBS 대신 $0.1 \%$ bovine serum albumin (BSA)을 넣어준다.

\section{WST assay}

세포증식 측정은 WST assay kit인 EZ-CYTOX (Daeillab service, Co., Seoul, Korea)를 이용하여 시행하였다. 업체에서 제공한 사용 법을 일부 변경하여 진행하였다. $1 \times 10^{5}$ 개의 세포를 다양한 농도 $(0,1 \mathrm{nM}, 10 \mathrm{nM}, 100 \mathrm{nM}, 1 \mu \mathrm{M})$ 의 zerumbone과 함께 $200 \mu \mathrm{L}$ 배 양액에 넣어 96 well plate에 분주하였다. $37^{\circ} \mathrm{C}, 5 \% \mathrm{CO}_{2}$ 조건에서 10 시간 배양 후, Ez-CYTOX 시약 $10 \mu \mathrm{L}$ 을 각 well에 첨가하였다. 2시간의 추가 배양 후 마이크로플레이트 리더 Sunrise (Tecan Co., Männedorf, Switzerland)를 이용하여 $450 \mathrm{~nm}$ 에서 흡광도를 측 정하였다.

\section{Transwell migration assay}

세포 이동 평가를 위해 $8 \mu \mathrm{m}$ pore size의 falcon cell culture inserts (Corning Co., NY, USA)와 24 wells 짜리 falcon companion tissue culture plate (Corning Co., NY, USA)를 사용하였다. 실험 은 migration buffer (RPMI 1640, 10 mM HEPES, pH 7.4, 0.1\% 
$\mathrm{BSA}$ 를 이용하여 진행하였고, 실험 전 세포는 migration buffer와 함께 $37^{\circ} \mathrm{C}, 5 \% \mathrm{CO}_{2}$ 환경에서 2시간 동안 starvation 과정을 거쳤 다. 이후 조건 당 $2 \times 10^{5}$ 의 Jurkat 세포를 $200 \mu \mathrm{L}$ 의 migration buffer에 섞어 insert에 넣고, underwell에는 SDF-1 $\alpha$ 가 첨가된 migration buffer를 넣었다. 준비된 insert를 각 underwell에 삽입 하고 $37^{\circ} \mathrm{C}, 5 \% \mathrm{CO}_{2}$ 환경에서 배양하였다. 배양 후에 insert를 제거 하고 underwell로 이동한 세포들을 trypan-blue를 이용하여 염색 계수 하였다.

\section{5. 통계분석}

실험결과는 mean \pm S.D.로 표현하였다. ANOVA를 이용한 Student t-test를 통해 $p<0.05$ 이하인 경우를 유의한 것으로 판정 하였다.

\section{결 과}

\section{1. 다양한 농도의 zerumbone 처리 후 Jurkat 세포의 증식 변화}

$\mathrm{T}$ 림프구 세포주 Jurkat 세포를 다양한 농도의 zerumbone (0, 1 $\mathrm{nM}, 10 \mathrm{nM}, 100 \mathrm{nM}, 1 \mu \mathrm{M})$ 과 함께 10시간 배양했을 경우 세포 증 식은 별다른 변화가 없었다(Fig. 1).

\section{2. 다양한 농도의 SDF- $1 \alpha$ 와 배양 시간에 따른 Jurkat 세포 이동 변화}

조건당 $2 \times 10^{5}$ 개의 Jurkat 세포를 다른 농도의 SDF- $1 \alpha(0,100$ $\mathrm{ng} / \mathrm{mL}, 200 \mathrm{ng} / \mathrm{mL})$ 로 처리하여, $4 \mathrm{~h}, 10 \mathrm{~h}, 18 \mathrm{~h}$ 동안 배양한 후 underwell로 이동한 세포의 개수를 구하였다(Fig. 2). $4 \mathrm{~h}$ 동안 배 양했을 경우에는 SDF- $1 \alpha$ 에 의한 이동 증가 정도가 상대적으로 낮 았다. $10 \mathrm{~h}$ 배양했을 경우 $100 \mathrm{ng} / \mathrm{ml} \mathrm{SDF}-1 \alpha$ 는 약 5 배 정도의 이 동 증가를 나타냈으나, $200 \mathrm{ng} / \mathrm{ml}$ 으로 SDF- $1 \alpha$ 의 농도를 높여도

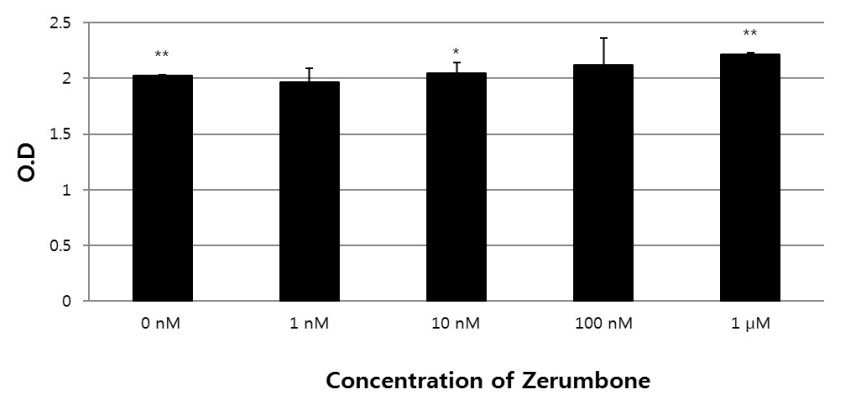

Fig. 1. Effect of zerumbone on the proliferation of Jurkat cell line. Cells were incubated with various concentrations of zerumbone. After $10 \mathrm{~h}$ of incubation, the proliferation was measured by WST assay. Values present mean $\pm S D$ of three separate experiments $\left({ }^{\star} p<0.05,{ }^{* *} p<0.01\right)$.
추가적인 증가는 관찰되지 않았다. 그러나, $18 \mathrm{~h}$ 배양을 했을 경우 $200 \mathrm{ng} / \mathrm{mL}$ 의 SDF- $1 \alpha$ 는 $100 \mathrm{ng} / \mathrm{mL}$ 보다 증가된 이동을 유발하 지만, $\mathrm{SDF}-1 \alpha$ 를 처리하지 않아도 $4 \mathrm{~h}, 10 \mathrm{~h}$ 배양 보다 증가된 이동 을 보였다.

\section{SDF-1 $\alpha$ 에 의해 유도된 Jurkat 세포 이동에서의 zerumbone} 효과

$\mathrm{SDF}-1 \alpha$ 에 의해 유도된 Jurkat 세포 이동에 zerumbone이 어떠 한 영향을 미치는지 알아보기 위해 transwell을 이용하여 실험을 진행하였다. 조건당 $2 \times 10^{5}$ 개의 Jurkat 세포를 다른 농도의 SDF- $1 \alpha$ $(0,100 \mathrm{ng} / \mathrm{mL}, 200 \mathrm{ng} / \mathrm{mL})$ 으로 자극하며 $10 \mathrm{~h}$ 을 배양하되, 두개



Fig. 2. SDF-1 $\alpha$ induced Jurakt cell migration. Cells were stimulated with various concentrations of SDF-1 $\alpha(0,100,200 \mathrm{ng} / \mathrm{mL})$. After various times of incubation, the cells having migrated to the underwells were counted through typan bleu exlusion counting method. The blank graph is the results of $4 \mathrm{~h}$ incubation, the grey is of $10 \mathrm{~h}$, and the black is $18 \mathrm{~h}$. Values present mean $\pm \mathrm{SD}$ of three separate experiments $\left({ }^{\star} p<0.05,{ }^{*} p<0.01\right)$.

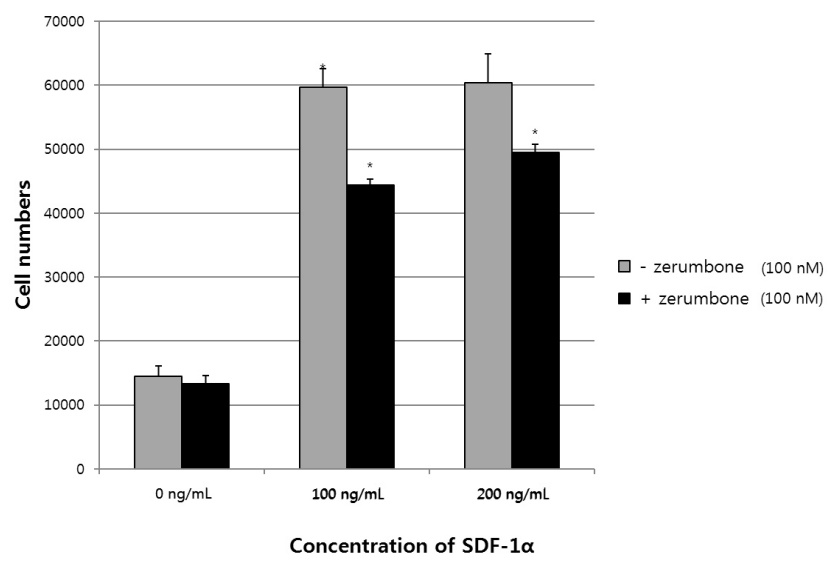

Fig. 3. Effect of zerumbone on the migration of Jurkat cell line. Cells were stimulated with $100 \mathrm{ng} / \mathrm{mL}$ and $200 \mathrm{ng} / \mathrm{mL}$ of SDF-1 $\alpha$ with or without zerumbone (100 nM). After 10h of incubation, the cells having migrated to the underwell were counted through trypan blue exclusion counting method. Values present mean \pm SD of three separate experiments $\left({ }^{\star} p<0.05,{ }^{*} p<0.01\right)$. 
의 그룹으로 나누어 한 그룹은 zerumbone $100 \mathrm{nM}$ 을 넣어주고 배 양을 진행하였고, 다른 그룹은 zerumbone 없이 배양을 진행하였 다. 배양 후 underwell로 이동한 Jurkat 세포들을 trypan-blue를 이용하여 염색계수 하였다. SDF- $1 \alpha$ 로 자극하지 않은 basal level 의 이동은 zerumbone에 의해 영향을 받지 않은 것으로 관찰되었 다. 그러나, $100 \mathrm{ng} / \mathrm{mL}, 200 \mathrm{ng} / \mathrm{mL}$ 의 SDF-1 $1 \alpha$ 처리 그룹의 경우 zerumbone에 의해 각각 약 $25 \%, 17 \%$ 의 이동 감소가 나타났다 (Fig. 3).

\section{고 찰}

본 연구는 zerumbone이 T세포의 기능에 어떠한 영향을 미치는 지 알아보고자 진행되었다. 실험은 $\mathrm{T}$ 세포 연구에 주로 사용되는 Jurkat 세포주(clone E6-1)로 진행하였다. 우선적으로 T세포의 기 본 증식에 대한 zerumbone의 영향을 살펴보았다. WST assay를 통해 살펴본 결과, zerumbone은 기본적인 Jurkat 세포의 활성에 영향을 주지 않는 것으로 나타났다. $1 \mathrm{nM}$ 에서 $1000 \mathrm{nM}(1 \mu \mathrm{M})$ 까 지 다양한 농도로 zerumbone 처리를 해주었으나, zerumbone을 처리하지 않은 대조군과 비교하여 분명한 변화를 보이는 경우는 없 었다. 그렇지만, $100 \mathrm{nM}$ 부터 대조군에 비해 미세한 증식 증가의 경향을 보이는 것으로 미루어, zerumbone의 처리 농도를 높여 동 일한 실험을 시행할 필요성은 있을 것으로 사료된다. 또한 생리적 인 T세포를 이용하여 zerumbone의 증식에 대한 효과를 확인하는 것이 필요하다 여겨진다. Jurkat 세포는 immortalization을 통해 수립된 T세포이기 때문에, T세포 수용체(T cell receptor, TCR)와 Co-signal 분자에 의한 특이적 신호가 없어도 증식할 수 있다. 그러 므로, TCR/CD28로 유도되는 특이 T세포 증식에 대한 zerumobone의 영향을 알아보기 위해서는 생리적 T세포를 통한 확인 이 요구된다. 이와는 별도로, 첫번째 결과를 통해 본 연구에 사용된 zerumbone의 양 $(100 \mathrm{nM})$ 이 세포독성을 나타내지 않는다는 사실 도 확인할 수 있었다. zerumbone의 사용량을 결정하는 것은 중요 한 의미를 갖는다. Abdelwahab 등(2011)은 zerumbone이 급성T 세포백혈병 세포의 세포자멸사(apoptosis)를 유발함을 보고했다. 본 연구에 사용된 Jurkat 세포 역시 급성T세포백혈병 세포에서 유 래한 세포주 이지만, zerumbone 처리 후에도 세포사가 유발되지 는 않았다. 이같은 차이는 두 실험간 사용된 zerumbone의 양과 연 관이 있을 것으로 생각된다. Abdelwahab 등(2011)이 사용한 8.4 $\mu \mathrm{g} / \mathrm{mL}$ 의 zerumbone을 몰단위로 환산할 경우 약 $38 \mu \mathrm{M}$ 에 이르 며, 이는 본 연구에 사용된 zerumbone의 양보다 수백배 많은 양이 다. Park 등(2015)도 nitroc oxide (NO) 제공 화학물질인 sodium nitroprusside (SNP)를 저농도로 처리하였을 경우 $\mathrm{HaCaT}$ 세포의
증식이 유발되나, 고농도의 $\mathrm{SNP}$ (3 mM 이상)처리했을 경우에는 세포의 증식이 급격히 감소하며 세포자멸사를 유발한다는 점을 언 급하였다.

다음으로 zerumbone이 T세포의 이동에 미치는 영향을 알아보 기에 앞서, 본 연구에 맞는 적절한 $\mathrm{SDF}-1 \alpha$ 의 처리농도와 배양시간 을 결정하기 위하여 두가지 농도의 SDF- $1 \alpha$ 와 함께 $4,10,18 \mathrm{~h}$ 동 안 세포를 배양하며 T세포 이동 정도를 측정하였다. $100 \mathrm{ng} / \mathrm{mL}$ 의 $\mathrm{SDF}-1 \alpha$ 를 처리하며 4 시간을 배양했을 경우에 2.3 배의 이동 증가 가 발생한 반면, 10 시간을 배양했을 경우에는 약 4.1 배의 이동 증가 가 발생했음을 확인하였다. 배양시간을 18 시간으로 늘렸을 경우에 는 증가 정도가 1.7 배로 오히려 감소함을 나타냈다. $200 \mathrm{ng} / \mathrm{mL}$ 의 $\mathrm{SDF}-1 \alpha$ 를 처리하며 4 시간을 배양한 경우, 6.6 배의 이동 증가가 나 타났고, 10 시간 배양 후에는 4.1배 증가, 18 시간 배양 후에는 2.6 배 증가했다. 이러한 결과로 미루어 $100 \mathrm{ng} / \mathrm{mL}, 200 \mathrm{ng} / \mathrm{mL}$ 의 $\mathrm{SDF}-1 \alpha$ 를 10 시간 동안 처리하는 조건이 가장 적절한 이동을 유발 하는 것으로 판단되어, zerumbone 효과의 평가를 위해서 100 $\mathrm{ng} / \mathrm{mL}, 200 \mathrm{ng} / \mathrm{mL}$ 의 SDF- $1 \alpha$ 를 사용하여 10 시간 배양을 하기로 결정하였다. 앞서 결정한 조건에 $100 \mathrm{nM}$ 의 zerumbone을 추가하 여 이동 실험을 진행한 결과, $\mathrm{SDF}-1 \alpha$ 를 처리하지 않았을 경우 zerumbone은 Jurkat 세포의 이동에 거의 영향을 주지 않았으나, 다른 농도 $(100 \mathrm{ng} / \mathrm{mL}, 200 \mathrm{ng} / \mathrm{mL})$ 의 SDF- $1 \alpha$ 를 처리했을 경우에 는 zerumbone에 의해 $25 \%, 17 \%$ 의 이동 감소가 각각 발생하였다. 흥미로운 점은 $200 \mathrm{ng} / \mathrm{mL}$ 의 SDF- $1 \alpha$ 를 사용하여 이동을 유도하 였을 경우, 이동이 더 증가하지는 않았지만, zerumbone에 의한 이 동 감소는 $100 \mathrm{ng} / \mathrm{mL} \mathrm{SDF}-1 \alpha$ 를 사용하였을 때보다 적게 발생하 였다. 이는 고용량에 의한 과도한 이동 현상이 zerumbone의 작용 을 넘어선 결과로 생각된다. 이를 규명하기 위해서 SDF- $1 \alpha$ 에 의해 세포 내부에 유발되는 신호전달 체계가 zerumbone에 의해 어떻 게 변화되는지를 살펴볼 필요가 있다.

본 연구를 통해 $\mathrm{T}$ 세포의 증식과 이동에 대해 zerumbone이 나 타내는 효과를 간략하게 살펴 보았다. 향후에는 보다 더 많은 추가 연구가 요구된다. 특히 zerumbone의 이동 감소 효과 기전에 대한 연구가 우선적으로 필요하며, 이를 위해 먼저 시행할 수 있는 것은, $\mathrm{SDF}-1 \alpha$ 의 수용체인 CXCR4의 발현이 zerumbone에 의해 변화되 는지 여부를 확인하는 것이다. Sung 등(2008)은 zerumbone이 유 방암 세포주와 췌장암 세포주의 CXCR 4 발현을 감소시켜 SDF- $1 \alpha$ 에 의해 유도되는 종양세포 침입 현상을 막는다는 보고를 하였다. 또한, zerumbone이 백혈병 세포 내에서 G2/M 세포주기 집중, 미 토콘드리아 경로와 Fas 경로를 통한 세포자멸사를 유발한다는 보 고가 있으므로(Xian 등, 2007), 본 연구에서 사용된 세포배양 조건 하에서도 zerumbone에 의해 세포자멸사가 유도되는지 여부를 확 
인할 필요가 있다. 이를 통해 zerumbone의 작용이 실제로 세포의 이동을 감소시킨 것인지, 세포의 죽음을 유도함으로써 underwell 의 세포수가 감소한 것인지를 구별할 수 있을 것이다. 아울러, $\mathrm{SDF}-1 \alpha$ 에 의해 유발되는 신호전달 체계가 zerumbone에 의해 어 떻게 변화되는지 여부도 확인해야 한다. SDF- $1 \alpha$ 에 의해 T세포 내 에서 발생하는 주요 신호전달 현상은 ZAP-70과 Erk1/2의 인산화 증가이다(Alampour-Rajabi 등, 2015; Ticchioni 등, 2002). 이 두 분자의 인산화가 zerumbone에 의해 어떻게 변화하는지 확인하는 것은 본 연구에서 확인한 zerumbone의 이동 감소 효능의 생화학 적 기전을 설명하는 중요한 시발점이 될 수 있을 것이다.

\section{요 약}

야생 생강 Zingiber zerumbet Smith의 정유에 포함되어 있는 주요 성분인 zerumbone은 면역세포를 포함한 여러 종류의 세포 기능에 영향을 미치는 것으로 알려져 있다. 또한, 종양, 염증을 포함 한 여러 생물학적 환경에서 기능을 나타냄이 보고되었다. 본 연구 에서는 zerumbone이 SDF-1 $\alpha$ 로 유도된 T림프구 세포주 Jurkat 세포의 이동을 감소시키는 것을 transwell system을 이용하여 확 인하였다; $100 \mathrm{ng} / \mathrm{mL}$ 의 SDF- $1 \alpha$ 로 유발시킨 이동은 약 $25 \%, 200$ $\mathrm{ng} / \mathrm{mL}$ 의 SDF- $1 \alpha$ 로 유발시킨 경우에는 약 $17 \%$ 의 감소를 나타냈 다. 반면에, Jurkat 세포의 기본 증식에는 큰 변화를 유발하지 않는 다는 점을 WST assay를 통해 확인하였다. 이는 zerumbone이 지 닌 새로운 기능이지만, 향후 생리적 세포를 통해 다시 확인해야 하 며, zerumbone에 의한 세포자멸사 유발, CXCR4 발현 감소 등 세 포학적 기전 연구와 ZAP-70, Erk1/2의 인산화 변화 측정 등 생화 학적 기전 연구가 필요하다.

Acknowledgements: 이 논문은 2013학년도 세명대학교 교내학 술연구비 지원에 의해 수행된 연구임.

Funding: None

Conflict of interest: None

\section{References}

1. Abdelwahab SI, Abdul AB, Mohan S, Taha MM, Ibrahim MY, Mariod AA. Zerumbone induces apoptosis in T-acute lymphoblastic leukemia cells. Leuk Res. 2011, 35(2):268-271.

2. Alampour-Rajabi S, El Bounkari O, Rot A, Muller-Newen G, Bacheleri F, Gawaz M, et al. MIF interacts with CXCR7 to promote receptor internalization, ERK1/2 and ZAP-70 signaling, and lymphocyte chemotaxis. Faseb J. 2015, 29(11):4497-4511

3. Bordon Y. Lymphocyte migration: Travel agents for two. Nat
Rev Immunol. 2011, 11(2):77-88.

4. Eguchi A, Kaneko Y, Murakami A, Ohigashi H. Zerumbone suppresses phorbol ester-induced expression of multiple scavenger receptor genes in THP-1 human monocytic cells. BiosCi Biotechnol Biochem. 2007, 71(4):935-45.

5. Keong YS, Alitheen NB, Mustafa S, Abdul Aziz S, Abdul Rahman M, Ali AM. Immunomodulatory effects of zerumbone isolated from roots of Zingiber zerumbet. Pak J Pharm Sci. 2010, 23(1):75-82.

6. Kitayama T, Iwabuchi R, Minagawa S, Shiomi F, Cappiello J, Sawada S, et al. Unprecedented olefin-dependent histidinekinase inhibitory of zerumbone ring-opening material. Bioorg Med Chem Lett. 2004, 23:5943-5946.

7. Murakami A, Hayashi R, Tanaka T, Kwon KH, Ohigashi H, Safitri R. Suppression of dextran sodium sulfate-induced colitis in mice by zerumbone, a subtropical ginger sesquiterpene, and nimesulide: separately and in combination. Biochem Pharmacol. 2003, 66(7):1253-1261.

8. Murakami A, Ohigashi H. Cancer-preventive anti-oxidants that attenuate free radical generation by inflammatory cells. Biol Chem. 2006, 387(4):387-392.

9. Murakami A, Song M, Katsumata S, Uehara M, Suzuki K, Ohigashi H. Citrus nobiletin suppresses bone loss in ovariectomized ddY mice and collagen-induced arthritis in DBA/1J mice: possible involvement of receptor activator of NF-kappaB ligand (RANKL)-induced osteoclastogenesis regulation. Biofactors. 2007, 30(3):179-192.

10. Park YR, Moon C, Kim SH, Lee PJ. Induction of HaCaT cell apoptosis by sodium nitroprusside. Korean J Clin Lab Sci. 2015, 47(3):112-116.

11. Perimal EK, Akhtar MN, Mohamad AS, Khalid MH, Ming OH, Khalid S, et al. Zerumbone-induced antinociception: involvement of the L-arginine-nitric oxide-cGMP -PKC-K+ ATP channel pathways. Basic Clin Pharmacol Toxico. 2011, 1108(3): 155-162.

12. Shanmugam MK, Rajendran P, Li F, Kim C, Sikka S, Siveen KS, et al. Abrogation of STAT3 signaling cascade by zerumbone inhibits proliferation and induces apoptosis in renal cell carcinoma xenograft mouse model. Mol Carcinog. 2015, 54(10): 971-985.

13. Sulaiman MR, Perimal EK, Akhtar MN, Mohamad AS, Khalid $\mathrm{MH}$, Tasrip NA, et al. Anti-inflammatory effect of zerumbone on acute and chronic inflammation models in mice. Fitoterapia. 2010, 81(7):855-858.

14. Sulaiman MR, Perimal EK, Zakaria ZA, Mokhtar F, Akhtar MN, Lajis NH, et al. Preliminary analysis of the antinociceptive activity of zerumbone. Fitoterapia. 2009, 80(4):230-232.

15. Sung B, Jhurani S, Ahn KS, Mastuo Y, Yi T, Guha S, et al. Zerumbone down-regulates chemokine receptor CXCR4 expression leading to inhibition of CXCL12-induced invasion of breast and pancreatic tumor cells. Cancer Res. 2008, 68(21): 8938-8944

16. Taha MM, Abdul AB, Abdullah R, Ibrahim TA, Abdelwahab SI, Mohan S. Potential chemoprevention of diethylnitrosamine- initiated and 2-acetylaminofluorene-promoted hepatocarcinogenesis by zerumbone from the rhizomes of the subtropical ginger (Zingiber zerumbet). Chem Biol Interact. 2010, 186(3): 
295-305.

17. Ticchioni M, Charvet C, Noraz N, Lamy L, Steinberg M, Bernard A, et al. Signaling through ZAP-70 is required for CXCL12mediated T-cell transendothelial migration. Blood. 2002, 99(9): 3111-3118.

18. Xian M, Ito K, Nakazato T, Shimizu T, Chen CK, Yamato K, et al. Zerumbone, a bioactive sesquiterpene, induces G2/M cell cycle arrest and apoptosis in leukemia cells via a Fas- and mitochondria-mediated pathway. Cancer SCi. 2007, 98(1):118-126.

19. Zhang S, Liu Q, Liu Y, Oiao H, Liu Y. Zerumbone, a Southeast Asian ginger sesquiterpene, induced apoptosis of pancreatic carcinoma cells through p53 signaling pathway. Evid Based Complement Alternat Med. 2012, 2012:936030. 